\title{
Mirna interference in human pulmonary alveolar epithelial cells (HPAEPIC) undergoing cyclic stretch and in ex vivo ventilated and perfused rat lungs
}

A Ferruelo ${ }^{1,2^{*}}$, B Olaiz $^{1,3}$, R Herrero ${ }^{1,2}$, E Lopez ${ }^{1}$, A Esteban ${ }^{1}$, JÁ Lorente ${ }^{1,2,3}$

From ESICM LIVES 2015

Berlin, Germany. 3-7 October 2015

\section{Introduction}

We have previously demonstrated that the expression of miRNA 27a-5p is associated with DAD in an experimental model of ventilator-induced lung injury and in patients with ARDS.

\section{Objectives}

To modulate miRNA 27a-5p expression in HPAEPiC undergoing stretch and in ex vivo ventilated perfused lungs.

\section{Methods}

HPAEPiCs were transfected overnight with miRNA 27a$5 \mathrm{p}$ inhibitor (10 nM, $20 \mathrm{nM}$ and $50 \mathrm{nM})$ or mimic $(20$ $\mathrm{nM}, 40 \mathrm{nM}$ ) or the negative control inhibitor (Exiqon) using HiPerfect transfection agent and underwent cyclic stretch for $6 \mathrm{~h}$ ( $15 \%$ linear elongation, $0.2 \mathrm{~Hz}$ ). Cells were then cultured for up to $48 \mathrm{~h}$ for miRNA isolation (miRNeasy Mini Kit, Qiagen) and for $72 \mathrm{~h}$ for protein isolation (T-Per, Pierce). All assays were performed in triplicate.

Adult male Sprague-Dawley rats (weight 325-375 g) were anesthetized and sacrificed by exsanguination, and the heart and lung were extracted en bloc and mounted in a ventilation chamber for perfusion (Krebs solution) and ex vivo ventilation for $2.5 \mathrm{~h}(\mathrm{VT}=6 \mathrm{~mL} / \mathrm{kg}, \mathrm{PEEP}=5 \mathrm{~cm}$ H2O (Harvard Apparatus, MA). miRNA 27a-5p inhibitor ( 0.25 and $0.50 \mathrm{mg} / \mathrm{kg}$ lung weight), its corresponding controls, as well as miRNA $27 \mathrm{a}-5 \mathrm{p}$ mimic $(0.10 \mathrm{mg} / \mathrm{kg})$ were administered intratracheally $30 \mathrm{~min}$ before mechanical ventilation ( $\mathrm{n}=5$ for each of the 5 groups).

${ }^{1}$ Hospital Universitario de Getafe, Getafe, Spain

Full list of author information is available at the end of the article
Expression of miRNA 27a-5p was quantified by RTqPCR (miScript II RT and QuantiTect SYBR Green PCR, Qiagen) in a 7500 Fast Real-Time PCR (Life Technologies) and data were analyze with the $\Delta \Delta C T$ method. Epidermal growth factor receptor (EGFR) protein concentration, a miRNA 27a-5p target, was measured in cell and tissue lysates for Elisa.

Values were compared by the Kruskal-Wallis method. The study was conducted with the approval of the local IRB. Values are fold change as compared to the negative control, or median (IQR). $\mathrm{p}<0.05$ was considered statistically significant.

\section{Results}

Treatment with the miRNA 27a-5p inhibitor dose dependently decreased miRNA $27 \mathrm{a}-5 \mathrm{p}$ expression vs. negative

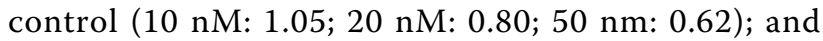
increased EGFR concentration vs negative control $(10 \mathrm{nM}$ : 1.20; $20 \mathrm{nM}: 1.36 ; 50 \mathrm{nM}: 1.45)$. Treatment with the miRNA 27a-5p mimic increased miRNA 27a-5p expression (20 nM: 150; $40 \mathrm{nM}: 200)$ and decreased EGFR concentration (20 nM: 0.79; $40 \mathrm{nM}$ : 0.78).

In lung tissue, miRNA 27a-5p inhibitor down-regulated miRNA 27a-5p expression $\left(46 \times 10-4\left(42 \times 10^{-4}-54 \times 10^{-4}\right)\right.$ vs. $15 \times 10^{-4}\left(10 \times 10^{-4}-54 \times 10^{-4}\right)$ and $76 \times 10^{-4}(57 \times$ $\left.10^{-4}-93 \times 10^{-4}\right)$ vs. $\left.11 \times 10^{-4}\left(8 \times 10^{-4}-20 \times 10^{-4}\right)\right)$, for the $0.25 \mathrm{mg} / \mathrm{kg}$ and $0.50 \mathrm{mg} / \mathrm{kg}$ doses, respectively. EGFR concentration increased with the $0.50 \mathrm{mg} / \mathrm{kg}$ dose $(0.17$ (0.41-0.47) vs. 0.42 (0.41-0.47) pg/ug protein).

miRNA 27a-5p mimic up-regulated miRNA 27a-5p expression $\left(3324 \times 10^{-4}\left(2023 \times 10^{-4}-4825 \times 10^{-4}\right)\right.$ vs 46 $\left.\times 10^{-4}\left(42 \times 10^{-4}-54 \times 10^{-4}\right)\right)$ and reduced EGFR concentration $(0.34(0.22-0.43)$ vs. $0.11(0.08-0.20)$. 


\section{Conclusions}

It is possible to modulate in vitro and ex vivo the expression of miRNA 27a-5p, a miRNA associated with DAD.

\section{Funding}

Fis PI12/2898 and FEDER Funds

\section{Authors' details}

${ }^{1}$ Hospital Universitario de Getafe, Getafe, Spain. ${ }^{2}$ Ciber de Enfermedades

Respiratorias, Madrid, Spain. ${ }^{3}$ Universidad Europea, Madrid, Spain.

Published: 1 October 2015

doi:10.1186/2197-425X-3-S1-A566

Cite this article as: Ferruelo et al:: Mirna interference in human

pulmonary alveolar epithelial cells (HPAEPIC) undergoing cyclic stretch

and in ex vivo ventilated and perfused rat lungs. Intensive Care Medicine

Experimental 2015 3(Suppl 1):A566.

\section{Submit your manuscript to a SpringerOpen ${ }^{\circ}$ journal and benefit from:}

- Convenient online submission

- Rigorous peer review

- Immediate publication on acceptance

- Open access: articles freely available online

- High visibility within the field

- Retaining the copyright to your article

Submit your next manuscript at $>$ springeropen.com 